\title{
HER2 amplification level is not a prognostic factor for HER2- positive breast cancer with trastuzumab-based adjuvant treatment: a systematic review and meta-analysis
}

\author{
Qian-Qian Xu' ${ }^{1}$, Bo Pan ${ }^{1}$, Chang-Jun Wang ${ }^{1}$, Yi-Dong Zhou ${ }^{1}$, Feng Mao ${ }^{1}$, Yan Lin ${ }^{1}$, \\ Jing-Hong Guan ${ }^{1}$, Song-Jie Shen ${ }^{1}$, Xiao-Hui Zhang ${ }^{1}$, Ya-Li Xu ${ }^{1}$, Ying Zhong ${ }^{1}$, \\ Xue-Jing Wang ${ }^{1}$, Yan-Na Zhang ${ }^{1}$, Qiang Sun ${ }^{1}$ \\ ${ }^{1}$ Department of Breast Surgery, Peking Union Medical College Hospital, Chinese Academy of Medical Sciences and Peking \\ Union Medical College, Beijing 100730, P. R. China
}

Correspondence to: Qiang Sun, email: sunqiangpumc@126.com

Keywords: HER2-positive breast cancer, HER2 amplification, prognosis, trastuzumab-based treatment, adjuvant setting

Received: June 21, 2016

Accepted: August 17, 2016

Published: August 23, 2016

\section{ABSTRACT}

Background: Trastuzumab-based therapy is a standard, targeted treatment for HER2-positive breast cancer in the adjuvant setting. However, patients do not benefit equally from it and the association between HER2 amplification level and patients' survival remains controversial. A systematic review and meta-analysis was conducted by incorporating all available evidence to evaluate the association between disease free survival (DFS) and HER2 amplification level.

Results: Three cohort studies involving 1360 HER2-positive breast cancer patients stratified by HER2 amplification magnitude were eligible for meta-analysis. The combined HRs for DFS were 1.05 (95\% CI: $0.80-1.36, p=0.74)$ and $0.97(95 \%$ CI: $0.73-1.29, p=0.83$ ) for HER2 gene copy number (GCN) and HER2/CEP 17 ratio. No evidence of heterogeneity or public bias was found.

Methods: Databases including PubMed, Embase, Web of Science, and Cochrane Central Register of Controlled Trials (CENTRAL), were searched for eligible literature. HER2 amplification level was evaluated by fluorescence in situ hybridization (FISH) in terms of gene copy number (GCN) and HER2/CEP17 ratio. Hazard ratios (HRs) for DFS with $95 \%$ confidence interval (CI) according to the amplification level of HER2 were extracted. The outcomes were synthesized based on a fixed-effects model.

Conclusions: HER2 amplification level is not a prognostic factor for HER2-positive breast cancer with trastuzumab-based targeted therapy in the clinical adjuvant setting.

\section{INTRODUCTION}

The human epidermal growth factor receptor 2 (HER2) is a 185-kd glycoprotein with tyrosine kinase activity. HER2 protein overexpression or gene amplification (HER2 positivity) occurs in approximately $20 \%$ to $30 \%$ of newly diagnosed invasive breast cancers. HER2 positivity has been shown to confer an adverse prognosis [1-3] and serve as a predictor of clinical response to treatment with the humanized monoclonal antibody trastuzumab [4, 5]. Trastuzumab shows considerable clinical efficacy and extends the overall survival of certain patients with HER2-positive breast cancer [6-10]. However, heterogeneity exists within HER2-positive tumors, and the overall response rate to trastuzumab-containing therapies remains modestapproximately $26 \%$ when used as a single therapy and $40 \%$ to $60 \%$ when used in combination with systemic chemotherapy $[8,10,11]$.

Studies have been conducted to investigate the relationship between HER2 status and response to trastuzumab or clinical outcomes in HER2-positive breast cancer cohorts with trastuzumab-containing treatment. All related studies are summarized in Table 1 [12-39]. All included participants were HER2-positive breast cancer patients who received trastuzumab-based therapy according to the standard dose regimen. HER2 status of primary tumor or serum was assessed at a minimum of one of three levels including DNA, RNA, and protein. In a neoadjuvant setting, both DNA amplification and 
Table 1: Correlations between HER2 levels and response to trastuzumab or survival

\begin{tabular}{|c|c|c|c|c|c|c|}
\hline \multicolumn{7}{|c|}{ Neoadjuvant setting } \\
\hline Level & Sample & Study & Population & Method & Result & Conclusion \\
\hline \multirow[t]{2}{*}{ DNA } & \multirow[t]{2}{*}{ tissue } & $\begin{array}{l}\text { Laurent Arnould } / 2007 \\
\text { Clin cancer res }\end{array}$ & $\begin{array}{l}\text { HER2 }(+) \text { locally } \\
\text { advanced BC } \\
\text { T-based therapy }\end{array}$ & FISH & $\begin{array}{l}\text { High HER2 amplification level--- } \\
\text {-high pCR rate }\end{array}$ & Positive correlation with response \\
\hline & & $\begin{array}{l}\text { S Guiu/2010 } \\
\text { British journal of } \\
\text { cancer }\end{array}$ & $\begin{array}{l}\text { HER2 }(+) \text { BC } \\
\text { T-based therapy }\end{array}$ & FISH & $\begin{array}{l}\text { High HER2 amplification level--- } \\
\text {-high pCR rate } \\
\text { The level of HER2 gene } \\
\text { amplification did not influence } \\
\text { RFS or OS. }\end{array}$ & $\begin{array}{l}\text { Positive correlation with response } \\
\text { No correlation with survival }\end{array}$ \\
\hline mRNA & tissue & $\begin{array}{l}\text { Andreas } \\
\text { Schneeweiss/2014 } \\
\text { Breast cancer } \\
\text { research }\end{array}$ & $\begin{array}{l}\text { HER2 }(+) \text { EBC } \\
\text { T plus pertuzumab }\end{array}$ & qRT-PCR & $\begin{array}{l}\text { High HER } 2 \text { mRNA expression } \\
\text { level----high pCR rate }\end{array}$ & Positive correlation with response \\
\hline \multirow[t]{2}{*}{ Protein } & \multirow[t]{2}{*}{ tissue } & $\begin{array}{l}\text { Laurent Arnould } / 2007 \\
\text { Clin cancer res }\end{array}$ & $\begin{array}{l}\text { HER2 }(+) \text { locally } \\
\text { advanced BC } \\
\text { T-based therapy }\end{array}$ & $\begin{array}{l}\text { IHC, HercepTest scoring } \\
\text { system }(0,1+, 2+, 3+)\end{array}$ & No correlation with $\mathrm{pCR}$ rate & No correlation with response \\
\hline & & $\begin{array}{l}\text { Andreas } \\
\text { Schneeweiss/2014 } \\
\text { Breast cancer } \\
\text { research }\end{array}$ & HER2 (+) EBC & IHC, H-Score $(0 \sim 400)$ & $\begin{array}{l}\text { High HER2 protein expression } \\
\text { level----high pCR rate }\end{array}$ & Positive correlation with response \\
\hline \multicolumn{7}{|c|}{ Adjuvant setting } \\
\hline \multirow[t]{5}{*}{ DNA } & \multirow[t]{5}{*}{ tissue } & $\begin{array}{l}\text { S. Paik/2007 } \\
\text { Journal of Clinical } \\
\text { Oncology }\end{array}$ & $\begin{array}{l}\text { HER2 }(+) \text { BC } \\
\text { T-based therapy }\end{array}$ & FISH & No correlation with DFS & No correlation with survival \\
\hline & & $\begin{array}{l}\text { Mitch Dowsett } / 2009 \\
\text { Journal of clinical } \\
\text { oncology }\end{array}$ & $\begin{array}{l}\text { HER2 }(+) \text { BC } \\
\text { T-based therapy }\end{array}$ & FISH & No correlation with DFS & No correlation with survival \\
\hline & & $\begin{array}{l}\text { Edith A. Perez/2010 } \\
\text { Journal of clinical } \\
\text { oncology }\end{array}$ & $\begin{array}{l}\text { HER2 }(+) \text { BC } \\
\text { T-based therapy }\end{array}$ & FISH & No correlation with DFS & No correlation with survival \\
\hline & & $\begin{array}{l}\text { A Borley/2014 } \\
\text { British journal of } \\
\text { cancer }\end{array}$ & $\begin{array}{l}\text { HER2 }(\text { IHC2 }+ \\
\text { FISH +) BC } \\
\text { T-based therapy }\end{array}$ & FISH & $\begin{array}{l}\text { High and low level HER2 } \\
\text { amplification levels----longer } \\
\text { DFS than intermediate level }\end{array}$ & Parabolic correlation with survival \\
\hline & & $\begin{array}{l}\text { Qijia Xuan/2015 } \\
\text { Breast cancer res treat }\end{array}$ & $\begin{array}{l}\text { HER2 }(+) \text { BC } \\
\text { T-based therapy }\end{array}$ & FISH & $\begin{array}{l}\text { High HER2 amplification level--- } \\
\text {-shorter DFS }\end{array}$ & Negative correlation with survival \\
\hline \multirow[t]{2}{*}{ Protein } & \multirow[t]{2}{*}{ tissue } & $\begin{array}{l}\text { S. Paik } / 2007 \\
\text { Journal of Clinical } \\
\text { Oncology }\end{array}$ & $\begin{array}{l}\text { HER2 }(+) \text { BC } \\
\text { T-based therapy }\end{array}$ & $\begin{array}{l}\text { IHC, HercepTest scoring } \\
\text { system }(0,1+, 2+, 3+)\end{array}$ & No correlation with DFS & No correlation with survival \\
\hline & & $\begin{array}{l}\text { H. Joensuu/2011 } \\
\text { Annals of oncology }\end{array}$ & $\begin{array}{l}\text { HER2 }(+) \text { EBC } \\
\text { T-based therapy }\end{array}$ & $\begin{array}{l}\text { HERmark } \\
\text { H2T }\end{array}$ & $\begin{array}{l}\text { Very high tumor HER2 content } \\
(\log \mathrm{H} 2 \mathrm{~T} \geq 2.1) \text {----less benefit } \\
\text { from } \mathrm{T}\end{array}$ & Negative correlation with benefit \\
\hline \multicolumn{7}{|c|}{ Metastatic setting } \\
\hline \multirow[t]{6}{*}{ DNA } & \multirow[t]{6}{*}{ tissue } & $\begin{array}{l}\text { Rosa Giuliani/2007 } \\
\text { European journal of } \\
\text { cancer }\end{array}$ & $\begin{array}{l}\text { HER2 }(+) \text { MBC } \\
\text { T-based therapy }\end{array}$ & FISH & $\begin{array}{l}\text { Increased HER } 2 / C E P 17 \text { ratio---- } \\
\text { high response rate }\end{array}$ & Positive correlation with response \\
\hline & & $\begin{array}{l}\text { P. A. Kaufman } / 2007 \\
\text { Journal of Clinical } \\
\text { Oncology }\end{array}$ & $\begin{array}{l}\text { HER2 }(+) \text { MBC } \\
\text { T-based therapy }\end{array}$ & FISH & $\begin{array}{l}\text { High amplification level----higher } \\
\text { response rate }\end{array}$ & Positive correlation with response \\
\hline & & $\begin{array}{l}\text { Giuseppe Gullo/2009 } \\
\text { Invest new drugs }\end{array}$ & $\begin{array}{l}\text { HER2 }(+) \text { MBC } \\
\text { T-based therapy }\end{array}$ & FISH & $\begin{array}{l}\text { High HER2 amplification } \\
\text { level----shorter TTP and OS(no } \\
\text { statistical significance) }\end{array}$ & No correlation with survival \\
\hline & & $\begin{array}{l}\text { Hye-Suk Han/2009 } \\
\text { J Korean Med Sci }\end{array}$ & $\begin{array}{l}\text { HER2 }(\mathrm{FISH}+) \\
\text { MBC } \\
\text { first-line T-based } \\
\text { therapy }\end{array}$ & FISH & $\begin{array}{l}\text { High HER2 amplification level--- } \\
\text {-longer TTP }\end{array}$ & Positive correlation with survival \\
\hline & & $\begin{array}{l}\text { Ji-Won Kim/2013 } \\
\text { Cancer chemother } \\
\text { pharmacol }\end{array}$ & $\begin{array}{l}\text { HER2 (FISH }+) \\
\text { MBC } \\
\text { first-line T-based } \\
\text { therapy }\end{array}$ & FISH & $\begin{array}{l}\text { Patients with a HER } 2 / \text { CEP17 } \\
\text { ratio } \geq 3.0 \text { had significantly } \\
\text { longer PFS with a tendency } \\
\text { toward a higher RR and longer } \\
\text { OS }\end{array}$ & $\begin{array}{l}\text { Positive correlation with survival and } \\
\text { response }\end{array}$ \\
\hline & & $\begin{array}{l}\text { Eva-Maria } \\
\text { Fuchs/2014 } \\
\text { Int. J. cancer }\end{array}$ & $\begin{array}{l}\text { HER2 }(+) \text { MBC } \\
\text { T-based therapy }\end{array}$ & FISH & $\begin{array}{l}\text { High level HER2 amplification- } \\
\text {--longer PFS and improved CR } \\
\text { and PR }\end{array}$ & $\begin{array}{l}\text { Positive correlation with survival and } \\
\text { response }\end{array}$ \\
\hline
\end{tabular}




\begin{tabular}{|c|c|c|c|c|c|c|}
\hline \multirow[t]{2}{*}{ RNA } & \multirow[t]{2}{*}{ tissue } & \begin{tabular}{|l|} 
Maria \\
vassilakopoulou/2014 \\
Plos one
\end{tabular} & $\begin{array}{l}\text { HER2 (+) MBC } \\
\text { T-based therapy }\end{array}$ & RNAscope, AQUA & $\begin{array}{l}\text { High HER2 mRNA level---- } \\
\text { longer TTP survival and OS }\end{array}$ & Positive correlation with survival \\
\hline & & $\begin{array}{l}\text { Edith A perez/2014 } \\
\text { Breast cancer } \\
\text { research }\end{array}$ & $\begin{array}{l}\text { HER } 2(+) \text { MBC } \\
\text { HT or T-DM1 }\end{array}$ & qRT-PCR & $\begin{array}{l}\text { High HER2 mRNA----enhanced } \\
\text { improved PFS with T-DM1 } \\
\text { relative to HT(trastuzumab plus } \\
\text { docetaxel) }\end{array}$ & Positive correlation with survival \\
\hline \multirow[t]{13}{*}{ protein } & \multirow[t]{9}{*}{ tissue } & \begin{tabular}{|l|} 
Maurizio \\
Scaltriti/2007 \\
J Natl Cancer Inst
\end{tabular} & HER2 (+) MBC T & $\begin{array}{l}\text { Immunofluorescence } \\
\text { P95HER2 }\end{array}$ & $\begin{array}{l}\text { Breast tumors that express } \\
\text { p95HER2 were resistant to T. }\end{array}$ & Negative correlation with response \\
\hline & & $\begin{array}{l}\text { Rosa Giuliani/2007 } \\
\text { European journal of } \\
\text { cancer }\end{array}$ & $\begin{array}{l}\text { HER2 }(+) \text { MBC } \\
\text { T-based therapy }\end{array}$ & $\begin{array}{l}\text { IHC } \\
\text { p-HER2 }\end{array}$ & Activated p-HER2----high RR & Positive correlation with response \\
\hline & & \begin{tabular}{|l} 
Christine \\
Desmedt/2009 \\
Diagn mol pathol
\end{tabular} & $\begin{array}{l}\text { HER2 }(+) \text { MBC } \\
\text { T-based therapy }\end{array}$ & $\begin{array}{l}\text { VeraTag assay } \\
\text { Expression and dimer }\end{array}$ & $\begin{array}{l}\text { High HER2 expression or } \\
\text { HER2:HER2 dimer levels---- } \\
\text { longer TTP }\end{array}$ & Positive correlation with survival \\
\hline & & $\begin{array}{l}\text { Jeff Sperinde/2010 } \\
\text { Clin cancer res }\end{array}$ & HER2 (+) MBC T & $\begin{array}{l}\text { VeraTag FFPE assay } \\
\text { p95HER2 }\end{array}$ & $\begin{array}{l}\text { High p95HER2 expressing level- } \\
\text {---shorter PFS and OS }\end{array}$ & Negative correlation with survival \\
\hline & & $\begin{array}{l}\text { Allan Lipton/2010 } \\
\text { cancer }\end{array}$ & $\begin{array}{l}\text { HER2 (+) MBC } \\
\text { T-based therapy }\end{array}$ & $\begin{array}{l}\text { HERmark } \\
\text { H2T }\end{array}$ & $\begin{array}{l}\text { High HER2 expressing level---- } \\
\text { longer TTP }\end{array}$ & Positive correlation with survival \\
\hline & & $\begin{array}{l}\text { Masakaz Toil/2010 } \\
\text { BMC cancer }\end{array}$ & $\begin{array}{l}\text { HER2 }(+) \text { MBC } \\
\text { T-based therapy }\end{array}$ & $\begin{array}{l}\text { HERmark } \\
\text { H2T }\end{array}$ & $\begin{array}{l}\text { High HER2-expressing group: } \\
\text { higher H2T level----longer OS } \\
\text { Low HER2-expressing group: } \\
\text { lower H2T level----longer OS }\end{array}$ & $\begin{array}{l}\text { Positive correlation with survival in } \\
\text { high HER2-expressing group }\end{array}$ \\
\hline & & $\begin{array}{l}\text { M.Bates/2011 } \\
\text { Annals of oncology }\end{array}$ & $\begin{array}{l}\text { HER2 }(+) \text { MBC } \\
\text { T-based therapy }\end{array}$ & $\begin{array}{l}\text { HERmark } \\
\text { H2T }\end{array}$ & $\begin{array}{l}\text { Parabolic relationship: TTP } \\
\text { improved with increasing H2T } \\
\text { until, at the highest levels of H2T, } \\
\text { an abrupt decrease in the TTP } \\
\text { was observed. }\end{array}$ & $\begin{array}{l}\text { Positive correlation with survival } \\
\text { except the highest-level subgroup }\end{array}$ \\
\hline & & $\begin{array}{l}\text { Ji-Won Kim/2013 } \\
\text { Cancer chemother } \\
\text { pharmacol }\end{array}$ & $\begin{array}{l}\text { HER2 (FISH+) } \\
\text { MBC } \\
\text { first-line T-based } \\
\text { therapy }\end{array}$ & $\begin{array}{l}\text { IHC, HercepTest scoring } \\
\text { system }(0,1+, 2+, 3+)\end{array}$ & $\begin{array}{l}\text { Patients with HER2 IHC } 1+\text { had } \\
\text { significantly shorter OS, PFS and } \\
\text { lower RR than IHC } 2+/ 3+.\end{array}$ & Positive correlation with survival \\
\hline & & \begin{tabular}{|l|} 
Maria \\
vassilakopoulou/2014 \\
Plos one
\end{tabular} & $\begin{array}{l}\text { HER2 }(+) \text { MBC } \\
\text { T-based therapy }\end{array}$ & $\begin{array}{l}\text { Immunofluorescence } \\
\text { ICD, ECD }\end{array}$ & $\begin{array}{l}\text { High ICD and ECD expression--- } \\
\text {-longer TTP and OS }\end{array}$ & Positive correlation with survival \\
\hline & \multirow[t]{4}{*}{ serum } & $\begin{array}{l}\text { Wolfgang J. } \\
\text { Kostler/2004 } \\
\text { Clinical cancer } \\
\text { research }\end{array}$ & $\begin{array}{l}\text { HER2 (+) MBC } \\
\text { T-based therapy }\end{array}$ & ELISA & $\begin{array}{l}\text { 1. High baseline level----high } \\
\text { response rate } \\
\text { 2. Serial monitoring: 1)Decreased } \\
\text { ECD value----increased } \\
\text { probability of response, 2) } \\
\text { less decrease from baseline } \\
\text { HER2 concentration at day } 15 \\
\text {----shorter PFS }\end{array}$ & $\begin{array}{l}\text { Decreased HER2 concentration value- } \\
\text {---positive correlation with response } \\
\text { and survival }\end{array}$ \\
\hline & & \begin{tabular}{|l|} 
Francisco J \\
Esteva/2005 \\
Breast cancer \\
research
\end{tabular} & $\begin{array}{l}\text { HER2 }(+) \text { MBC } \\
\text { T-based therapy }\end{array}$ & $\begin{array}{l}\text { Bayer Immuno1 or } \\
\text { ADVIA Centaur } \\
\text { automated assay }\end{array}$ & $\begin{array}{l}\text { 1. Baseline HER2 concentrations- } \\
\text {---no correlation with PFS } \\
\text { 2. Serial monitoring: less } \\
\text { decrease from baseline HER2 } \\
\text { concentration in early weeks after } \\
\text { start of therapy----shorter PFS. }\end{array}$ & $\begin{array}{l}\text { Decreased HER2 concentration value-- } \\
\text {--positive correlation with survival }\end{array}$ \\
\hline & & \begin{tabular}{|l|} 
Sun-Young \\
Kong/2006 \\
Cancer res treat
\end{tabular} & $\begin{array}{l}\text { HER2 }(+) \text { MBC } \\
\text { T-based therapy }\end{array}$ & $\begin{array}{l}\text { ADVIA Centaur } \\
\text { immunoassay system }\end{array}$ & $\begin{array}{l}\text { 1. Baseline HER2 concentrations } \\
\text {---no correlation with response } \\
\text { rate } \\
\text { 2. Serial monitoring: Decrease } \\
\text { ECD value----increased } \\
\text { probability of response }\end{array}$ & $\begin{array}{l}\text { Decreased HER2 concentration value-- } \\
\text {--positive correlation with response }\end{array}$ \\
\hline & & $\begin{array}{l}\text { S. M. Ali/2006 } \\
\text { Journal of Clinical } \\
\text { Oncology }\end{array}$ & $\begin{array}{l}\text { HER2 (FISH+) } \\
\text { MBC } \\
\text { first-line T-based } \\
\text { therapy }\end{array}$ & ELISA & $\begin{array}{l}\text { Patients with }<20 \% \text { decrease in } \\
\text { serum HER- } 2 / \text { neu levels have } \\
\text { decreased benefit(ORR, DRP, } \\
\text { TTP, OS) from T therapy }\end{array}$ & $\begin{array}{l}\text { Decreased HER2 concentration value- } \\
\text {---positive correlation with response } \\
\text { and survival }\end{array}$ \\
\hline
\end{tabular}

Abbreviations: BC: breast cancer, DRP: duration of response, EBC: early breast cancer, ECD: HER2 extracellular domain, H2T: total HER2 content, ICD: HER2 intracellular domain, RFS: recurrence-free survival. 
mRNA expression positively correlated with response to trastuzumab[40-42]. There was a discrepancy at the protein level in the two studies, which used different scoring systems and found that the Hercept test scoring system may be not accurate enough to identify the correlation $[40,41]$. In metastatic setting, seven out of eight studies at DNA and mRNA level showed there was a positive correlation between HER2 amplification or mRNA expression level and response to trastuzumab or survival [43-49]. The only study that did not reach the limit of statistical significance was an explorative study with a small sample size of 33 [50]. Quantitative assessments of the HER2 protein level were done in both primary surgical specimen and serum samples. Serial monitoring of HER2 protein in serum after the beginning of trastuzumab treatment revealed that the decreased extent of HER2 concentration value was positively correlated with response and survival [51-54]. Expression level of HER2 protein or activated p-HER2 in tumor tissue was positively correlated with response and survival [43, 46, 47, 55-58]. Tumors that expressed p95HER2, an amino terminally truncated HER2 receptor that lacks the extracellular trastuzumab-binding domain, were resistant to trastuzumab and have a shorter progression free survival (PFS) and overall survival (OS) [59, 60]. In other words, HER2 level seems to be a positive predictive and prognostic factor for HER2-positive breast cancer in neoadjuvant or metastatic setting.

However, results from previous studies in adjuvant setting were controversial; three studies showed no correlation [61-63], one showed parabolic correlation [64], and one showed a negative correlation between HER2 amplification and clinical survival [65]. There was also no accordance for the relationship at the protein level, although different testing methods and scoring systems were used. These outcomes raised the question: Could HER2 amplification level assessed by FISH serve as a prognostic biomarker for clinical HER2 positive patients who receive standardized trastuzumab targeted therapy in an adjuvant setting? In this study, we performed a systematic review and meta-analysis by incorporating all available evidence to evaluate the DFS according to HER2 amplification level in patients with HER2-positive breast cancer.

\section{RESULTS}

\section{Study selection}

Figure 1 illustrates the flow diagram of candidate selection records in our study. The search retrieved 2,183 articles, of which 669 duplicates were identified. Of 1,514 remaining articles, 1,465 were excluded based on title and abstract reviewing and 49 references remained to achieve full text for further screening. Of these, full text was not available for five, 16 were not relevant, six were in the neoadjuvant or metastatic setting, one did not provide enough data, 11 assessed HER2 status with methods other than IHC or FISH, seven were reviews or comments or in other language, and only three satisfied inclusion criteria.

\section{Characteristics of included studies}

The main characteristics of the included studies are displayed in Table 2 [66-68]. The studies were conducted all over the world, including Europe, America, Asia, and Africa. Two were retrospective cohort studies and the other was a prospective cohort within a large international randomized clinical trial. The trastuzumabbased therapy applied in different studies was single trastuzumab therapy or in combination with traditional chemotherapy (mainly paclitaxel). All the studies adopted the immunohistochemistry (IHC) or FISH method to assess the HER2 status. The number of patients stratified by HER2/CEP17 ratio or (and) HER2 GCN ranged from 59 to 1000 . The follow-up period was long enough for the outcomes to occur. All the studies used DFS as the end point. The HER2 amplification was divided into high and low levels according to the original article and corresponding HRs for high to low HER2 amplification level are shown in Table 2. None of these three studies gained a Newcastle-Ottawa Quality Assessment Scale $(\mathrm{NOS})<6$, suggesting that all of them have high level of methodological quality in this meta-analysis.

\section{HER2 GCN and survival}

As shown in Figure 2A, there was no heterogeneity among these studies $\left(\mathrm{I}^{2}=0 \%, P=0.96\right)$. The fixed-effects model analysis showed that, the overall HR was $1.05(95 \%$ CI: $0.80-1.36, p=0.74)$, indicating that different HER2 GCN level had no prognostic value on the trastuzumabbased treatment outcomes in HER2-positive breast cancer patients.

\section{HER2/CEP17 ratio and survival}

Two studies assessed the clinical benefit from trastuzumab-based adjuvant therapy upon different HER2/ CEP17 ratio. Without heterogeneity $\left(\mathrm{I}^{2}=0 \%, P=0.58\right)$, a combined HR and its $95 \%$ CI were calculated with a fixed-effects model. The results did not show a statistically significant relationship between HER2/CEP17 ratio and survival ( $\mathrm{HR}=0.97,95 \% \mathrm{CI}: 0.73-1.29, p=0.83$ ) (Figure 2B) either.

\section{Publication bias}

No evidence of publication bias was indicated (Figure 2C and Figure 2D) in this study. However, because of the limited number of included studies, whether publication bias exists in the current meta-analysis is still difficult to confirm. 


\section{DISCUSSION}

This is a systematic review and meta-analysis to evaluate the prognostic value of HER2 gene amplification level in HER2-positive breast cancer patients undergoing trastuzumab-based adjuvant therapy after radical surgery treatment. Three studies assessed HER2 GCN and two studies assessed HER2/CEP17 ratio. Results showed that neither HER2 GCN nor HER2/CEP17 ratio had an impact on prognosis in the adjuvant treatment stage for HER2positive breast cancer. In other words, different HER2 amplification level does not associate with HER2-positive breast cancer prognosis in the adjuvant setting.

HER2 status is closely correlated with a therapeutic response to anti-HER2 treatment in neoadjuvant and metastatic settings. Previous studies showed higher HER2 amplification level was a favorable predictor for pathologic complete response (pCR) in a neoadjuvant

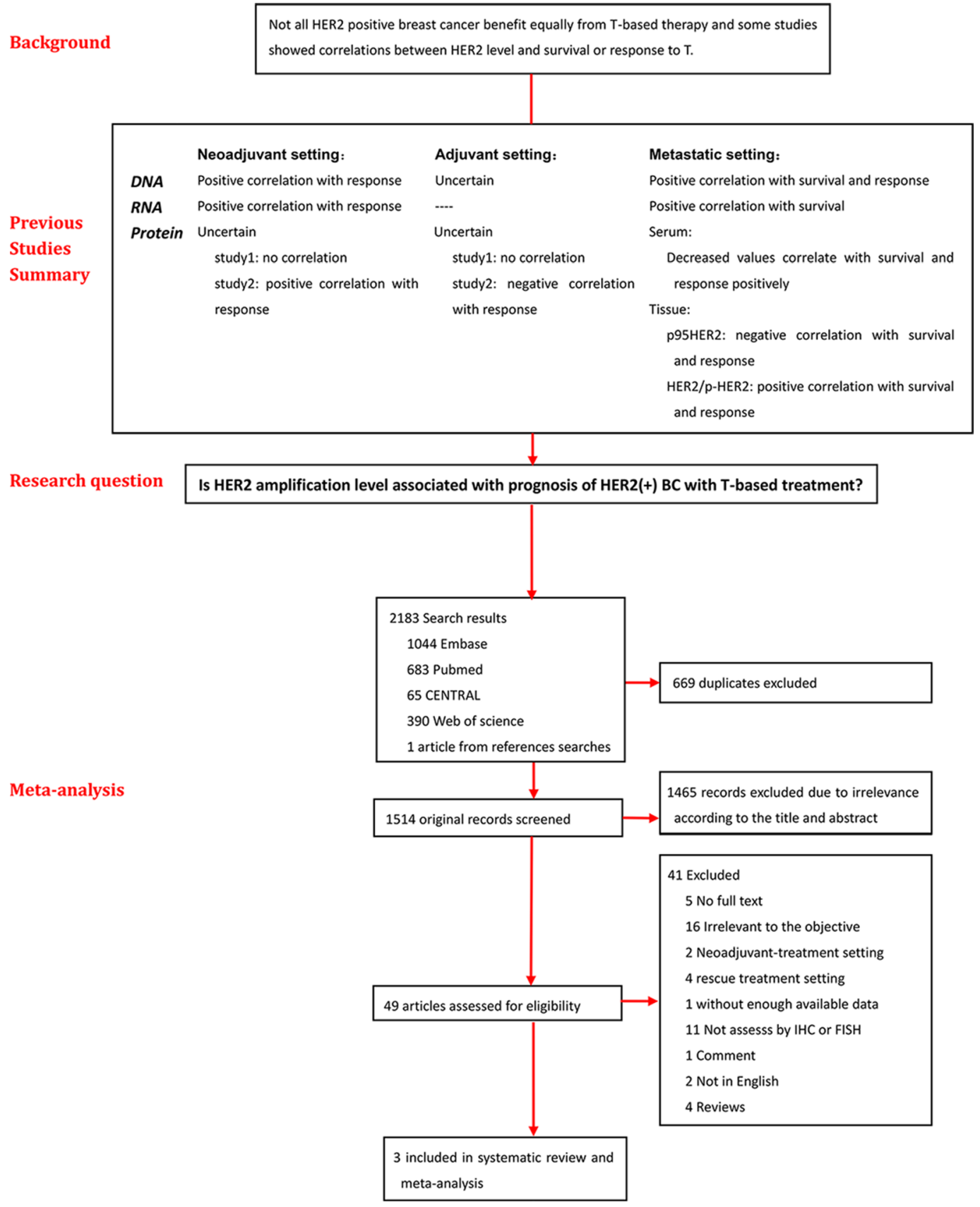

Figure 1: Flow chart of the research. Firstly, all available studies related with relationship between HER2 levels including DNA, RNA, and protein and clinical response to trastuzumab-containing therapies or survival were reviewed and summarized. Then a metaanalysis was performed in 3 studies to draw the relationship between HER2 amplification level and prognosis of HER2 positive breast cancer with trastuzumab-base therapy in adjuvant setting. Abbreviations: T-based, trastuzumab-based; BC, breast cancer. 
Table 2: Characteristics of studies included in the meta-analysis and the extracted HRs

\begin{tabular}{|c|c|c|c|c|c|c|c|c|c|c|c|}
\hline Study & Country & Study type & $\begin{array}{l}\text { Median } \\
\text { age }\end{array}$ & $\begin{array}{l}\text { Follow-up } \\
\text { period }\end{array}$ & $\begin{array}{l}\text { HER2 positive } \\
\text { criterion }\end{array}$ & $\begin{array}{l}\text { Stratus of HER2 } \\
\text { level }\end{array}$ & $\begin{array}{l}\text { Number } \\
\text { of patients } \\
\text { stratified } \\
\text { by HER2 } \\
\text { amplification }\end{array}$ & $\begin{array}{l}\text { Treatment } \\
\text { regiment }\end{array}$ & Endpoint & $\begin{array}{l}\text { HRs }(95 \% \\
\text { CI) }\end{array}$ & $\begin{array}{l}\text { Study } \\
\text { quality }\end{array}$ \\
\hline $\begin{array}{l}\text { Mitch } \\
\text { Dowsett/2009 } \\
\text { J Clin Oncol }\end{array}$ & $\begin{array}{l}\text { Argentina, } \\
\text { Australia, } \\
\text { Austria, et ala. }\end{array}$ & $\begin{array}{l}\text { Prospective } \\
\text { cohort within } \\
\text { Randomized } \\
\text { trial (HERA) }\end{array}$ & 49 & $\begin{array}{l}\text { Median: } 2 \\
\text { years }(0, \\
48 \text { months })\end{array}$ & $\begin{array}{l}\text { IHC3+ or/and } \\
\text { FISH amplified } \\
\text { IHC: at least } \\
10 \% \text { invasive } \\
\text { cells with } \\
\text { complete } \\
\text { membrane } \\
\text { staining } \\
\text { FISH: HER2/ } \\
\text { CEP17 ratio } \\
\geq 2.0\end{array}$ & $\begin{array}{l}\text { GCN: } \\
\text { Low: } 4 \leqq \text { HER } 2 \\
\text { GCN } \leqq 13 \\
\text { High: } 13<\text { HER2 } \\
\text { GCN } \\
\text { FISH ratio: } \\
\text { Low: } 2 \leqq \text { FISH } \\
\text { ratio } 5 \\
\text { High: } 6<\text { FISH } \\
\text { ratio }\end{array}$ & 1000 & $\begin{array}{l}\text { Control arm: } \\
\text { chemotherapy } \\
\rightarrow \text { observation } \\
\text { Test arm: } \\
\text { chemotherapy } \\
\rightarrow 1 \text { year } \mathrm{T}\end{array}$ & DFS & $\begin{array}{l}\text { GCN: } \\
1.03(0.86, \\
1.23) \\
\text { Ratio: } \\
1.00(0.83, \\
1.20)\end{array}$ & NOS 7 \\
\hline $\begin{array}{l}\text { A Borley/2014 } \\
\text { British } \\
\text { Journal of } \\
\text { Cancer }\end{array}$ & UK & $\begin{array}{l}\text { Retrospective } \\
\text { cohort study }\end{array}$ & 59 & 7years & $\begin{array}{l}\text { IHC2+ and } \\
\text { FISH amplified, } \\
\text { FISH: HER2/ } \\
\text { CEP17 ratio } \\
>2.0\end{array}$ & $\begin{array}{l}\text { GCN: } \\
\text { Low: } 2 \leqq \text { HER } 2 \\
\text { GCN } 12 \\
\text { High: } 12<\text { HER } 2 \\
\text { GCN }\end{array}$ & 59 & T-based therapy & PFS & $\begin{array}{l}3.90(0.43, \\
35.21)\end{array}$ & NOS 6 \\
\hline $\begin{array}{l}\text { Qijia } \\
\text { Xuan/2015 } \\
\text { Breast Cancer } \\
\text { Res Treat }\end{array}$ & China & $\begin{array}{l}\text { Retrospective } \\
\text { cohort study }\end{array}$ & $48(19-74)$ & $60+$ months & $\begin{array}{l}\text { FISH amplified: } \\
\text { a HER2/CEP17 } \\
\text { ratio } \geq 2.0 \text { or an } \\
\text { HER2/CEP17 } \\
\text { ratio }<2.0 \text { with } \\
\text { an average } \\
\text { HER2 GCN }> \\
6.0 \text { signals/cell }\end{array}$ & $\begin{array}{l}\text { GCN: } \\
\text { GCN }<11.5 \\
\text { GCN } \geq 11.5 \\
\text { FISH ratio: } \\
\text { FISH ratio }<6.5 \text {; } \\
\text { FISH ratio } \geq 6.5\end{array}$ & 291 & T-based therapy & DFS & $\begin{array}{l}\text { GCN: } \\
1.06(0.53, \\
2.12) \\
\text { Ratio: } \\
1.15(0.59, \\
2.25)\end{array}$ & NOS 8 \\
\hline
\end{tabular}

a:Belgium, Brazil, Canada, Chile, China, Colombia, Croatia, Denmark, France, Germany, Greece, Guatemala, Hong Kong, Hungary, Ireland, Israel, Italy, Japan, Korea, Republic of, Netherlands, Poland, Portugal, Russian Federation, Singapore, South Africa, Spain, Sweden, Switzerland, Thailand, United Kingdom.

setting [69-71]. In the metastatic setting, increasing values of HER2 amplification were associated with a significantly longer PFS or a significantly higher objective response rate (ORR) [72]. Therefore, it seemed consistent to regard a high level of HER2 amplification as a good predictive biomarker both for early HER2-positive breast cancer in the neoadjuvant treatment stage and HER2-positive $\mathrm{MBC}$ and as a prognostic biomarker for MBC. There were also other methodologies, including a quantitative measurement of HER2 protein by Vera Tag assay and assessment of HER 2 mRNA by qPCR or RNAscope, that have been applied and evaluated for the predictive value $[15-17,21,25,28]$. Those studies showed that higher HER2 protein and mRNA expression were significantly associated with higher $\mathrm{pCR}$ rate, higher response rate (RR), longer time to progression (TTP), longer PFS and OS in some trastuzumab-treated metastatic cohorts.

However, the relationship between the level of HER2 amplification and efficacy of trastuzumab-based therapy in adjuvant treatment remains controversial. We performed this systematic review and meta-analysis to summarize the results of all the relevant studies. This is the first metaanalysis to summarize the prognostic value of HER2 amplification level for HER2 positive early breast cancer in an adjuvant treatment setting. Results showed that HER2 GCN and HER2/CEP17 ratio did not influence prognosis in patients treated with trastuzumab-containing adjuvant comprehensive treatment. The $\mathrm{pCR}$ rate in neoadjuvant cannot be translated to survival benefit. When a tumor metastasizes to distant organs, the biological behavior of metastasis differs from the primary lesion. Therefore, the prognostic value of HER2 amplification level in palliative treatment cannot be applied in adjuvant treatment directly.
Although HER2 positivity indicates worse prognosis for breast cancer [1-3], the results of this metaanalysis indicated that further discriminating differences in HER2 amplification magnitude have insignificant prognostic value in adjuvant setting. It can be inferred that there might be a threshold effect that any degree of HER2 amplification above the cutoff value has similar clinical benefit from trastuzumab treatment. Surgeons and oncologists do not need to pay extra attention to patients' HER2 GCN and HER2/CEP17 ratio when already judged as amplification positive. Consequently, it highlights the importance to assess the HER2 positivity accurately to ensure the potential benefit.

However, significant heterogeneity exists among HER2-positive breast cancer patients as evidenced by the fact that some HER2-positive breast cancer patients exhibit de novo trastuzumab resistance, it is therefore necessary to identify the predictive markers. While mRNA and protein are downstream products of DNA and functionally related, it is reasonable to speculate that quantitative assessment of HER2 mRNA or protein may potentially identify the populations with different response and outcomes. So more studies especially prospective clinical trials concentrated on mRNA or protein level should be conducted in HER2-positive breast cancer population to identify these predictive markers.

This study was attempting to answer the question whether the amplification level of HER2 impacts patients' prognosis with HER2-positive breast cancer. Certain limitations existed and some results needed to be cautiously interpreted. First, we estimated the HR for DFS from Kaplan-Meier curves, which may have compromised the precision of the data. Second, the number of included 
studies and total sample size are relatively small, which might have impacted the validity of our analysis. The further elaboration is that the included three studies are the total data which are available to analyze and there do exist controversies between the conclusions retrieved from them. The other three studies listed in Table 1 were excluded because of lacking of full-text or analyzable data or being aimed at protein level. No heterogeneity and no evidence of publication bias was found. Third, cut-off values distinguishing high and low levels of HER2 amplification determined by FISH evaluation vary in studies and may have led to between-study heterogeneity.

\section{MATERIALS AND METHODS}

\section{Search strategy}

This meta-analysis was reported according to the Preferred Reporting Items for Systematic Reviews and Meta-analysis (PRISMA) statement [73]. Two authors independently carried out the systematical search for relevant randomized clinical trials and cohort studies in Pubmed, Embase, Web of science and the CENTRAL published before Jun. 19, 2015. Searches were limited to human studies in English, using combinations of the

\section{A HER2 Gene Copy Number and HR}

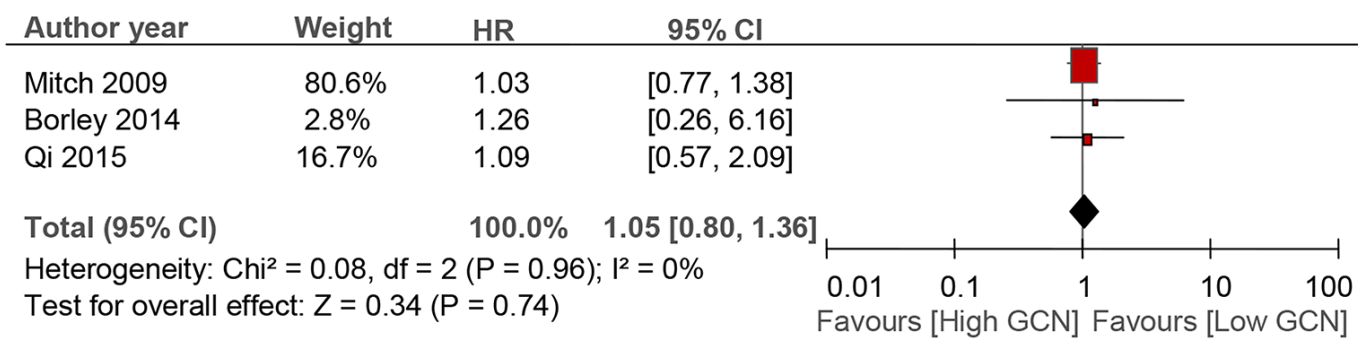

B

\section{HER2/CEP17 Ratio and HR}

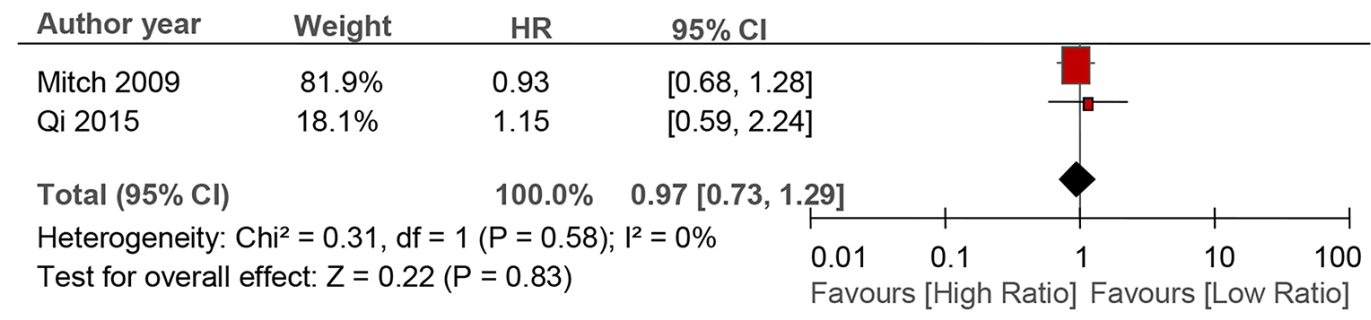

C

D

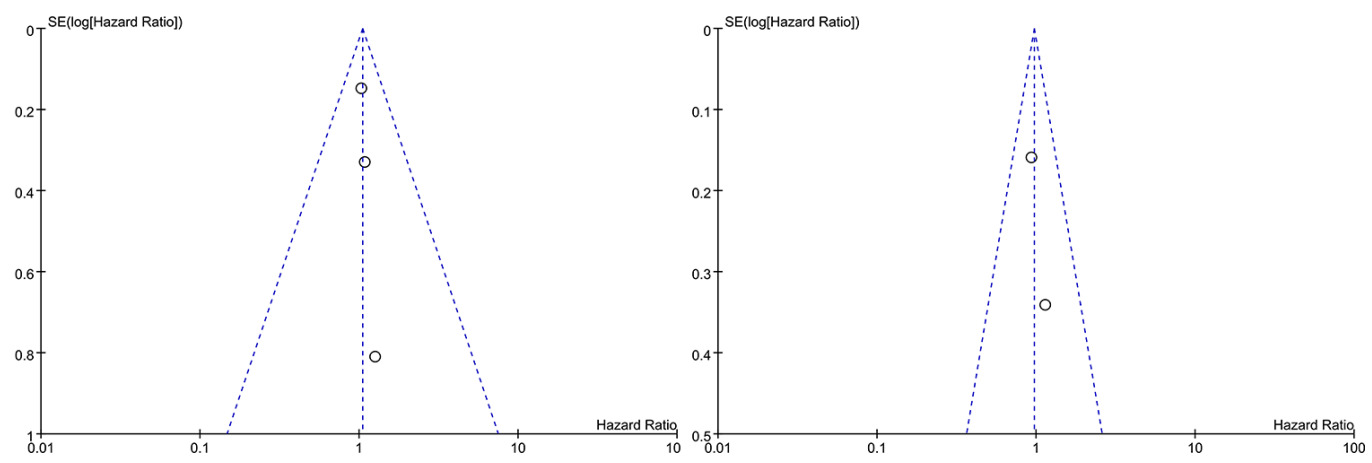

Figure 2: Forest plots and funnel plots. Forest plots showing relationship between HER2 amplification level and survival: (A) showing no relationship between HER2 gene copy number with DFS, and (B) showing no relationship between HER2/CEP17 ratio with DFS. Funnel plots for the evaluation of potential publication bias in the impact of HER2 GCN (C) or HER2/CEP17 ratio (D) on DFS with HER2 positive breast cancer. 
following search terms: "breast neoplasma", "breast cancer", "breast carcinoma", "mammary neoplasma", "mammary cancer", "mammary carcinoma", "genes, erbB-2”, "HER2”, “In Situ Hybridization, Fluorescence”, "prognosis" and "treatment outcome". We also manually reviewed relevant references and reviews.

\section{Inclusion and exclusion criteria}

Studies meeting the following criteria were eligible for the meta-analysis: (1) clinical trials or cohorts with full text; (2) participants within the study were ensured HER2-positive breast cancer patients assessed by IHC or (and) FISH and received trastuzumab no less than 1 year of adjuvant trastuzumab treatment; (3) the level of HER2 amplification was divided into at least two stratums; (4) survival data stratified by HER2 amplification level was available. Studies that failed to fulfill the above inclusion criteria were excluded from this study.

\section{Outcome definition and data extraction}

The primary end point for this meta-analysis was DFS. DFS data was extracted in the form of hazard ratio (HR) with the corresponding 95\% confidence interval (CI). All eligible publications were reviewed, and data extraction was done by two independent authors. The following information was extracted: (a) general information, including name of first author, year of publication, country (area) of origin, study type, age of the participants and follow-up period; (b) HER2 positive criterion, method to stratify HER2 amplification level and number of patients stratified by HER2 amplification; (c) treatment regiment and HRs for DFS with $95 \%$ confidence intervals.

\section{Quality assessment}

Two independent reviewers assessed the quality of each study with the NOS. A study with NOS $>5$ was regarded as a high-quality study. Disparity was resolved by discussion or consultation.

\section{Statistical analysis}

In this meta-analysis, HR and 95\% CI were used to assess the association of HER2 amplification level and DFS in patients with HER2 positive breast cancer. We estimated the HR and its 95\% CI with a previously validated method described by a previously published article [74]. When an article only had K-M curves, we used Engauge Digitizer, a digitizing program, that could translate curves into numbers to extract survival data from its curves, and then put the data into a spreadsheet, called Tierney table, by which the estimated HR and corresponding 95\% CI were calculated immediately. We assessed heterogeneity across studies with the Cochran $Q$ test and the $I^{2}$ statistic. An $I^{2}$ value less than
$50 \%$ was regarded as evidence of low heterogeneity, for which the fixed-effects model was utilized to pool the results;. Potential publication bias was assessed by visual inspection of the funnel plots, in which the standard error of $\log H \mathrm{R}$ of each study was plotted against its $\operatorname{logHR}$. We did not conduct further statistical tests for funnel plot asymmetry because of the limited test power when fewer than 10 studies were included [75]. A $p$ value $<0.05$ considered significant for all tests. All analyses were conducted using the Review Manager (RevMan) (Version 5.3. Copenhagen: The Nordic Cochrane Centre, the Cochrane Collaboration, 2014).

\section{CONCLUSIONS}

The present meta-analysis indicates that different HER2 amplification level is not associated with trastuzumab-based therapy response and clinical survival. The HER2 amplification should be assessed accurately to ensure enough appropriate treatment for HER2-positive breast cancer.

\section{ACKNOWLEDGMENTS AND FUNDING}

Xiao Gong performed statistical analysis. All authors read and approved the final article.

\section{CONFLICTS INTEREST}

There is no conflicts of interest of this study.

\section{REFERENCES}

1. Slamon DJ, Clark GM, Wong SG, Levin WJ, Ullrich A, McGuire WL. Human breast cancer: correlation of relapse and survival with amplification of the HER-2/neu oncogene. Science. 1987; 235:177-182.

2. Menard S, Casalini P, Tomasic G, Pilotti S, Cascinelli N, Bufalino R, Perrone F, Longhi C, Rilke F, Colnaghi MI. Pathobiologic identification of two distinct breast carcinoma subsets with diverging clinical behaviors. Breast Cancer Res Treat. 1999; 55:169-177.

3. Slamon DJ, Godolphin W, Jones LA, Holt JA, Wong SG, Keith DE, Levin WJ, Stuart SG, Udove J, Ullrich A, Et A. Studies of the HER-2/neu proto-oncogene in human breast and ovarian cancer. Science. 1989; 244:707-712.

4. Carter P, Presta L, Gorman CM, Ridgway JB, Henner D, Wong WL, Rowland AM, Kotts C, Carver ME, Shepard HM. Humanization of an anti-p185HER2 antibody for human cancer therapy. Proc Natl Acad Sci USA. 1992; 89:4285-4289.

5. Wolff AC, Hammond MEH, Hicks DG, Dowsett M, McShane LM, Allison KH, Allred DC, Bartlett JMS, Bilous M, Fitzgibbons P, Hanna W, Jenkins RB, Mangu PB, et al. Recommendations for Human Epidermal Growth 
Factor Receptor 2 Testing in Breast Cancer: American Society of Clinical Oncology/College of American Pathologists Clinical Practice Guideline Update. Arch Pathol Lab Med. 2014; 138:241-256.

6. Piccart-Gebhart MJ, Procter M, Leyland-Jones B, Goldhirsch A, Untch M, Smith I, Gianni L, Baselga J, Bell R, Jackisch C, Cameron D, Dowsett M, Barrios CH, et al. Trastuzumab after adjuvant chemotherapy in HER2positive breast cancer. N Engl J Med. 2005; 353:1659-1672.

7. Romond EH, Perez EA, Bryant J, Suman VJ, Geyer CJ, Davidson NE, Tan-Chiu E, Martino S, Paik S, Kaufman PA, Swain SM, Pisansky TM, Fehrenbacher L, et al. Trastuzumab plus adjuvant chemotherapy for operable HER2-positive breast cancer. N Engl J Med. 2005; 353:1673-1684.

8. Vogel CL, Cobleigh MA, Tripathy D, Gutheil JC, Harris LN, Fehrenbacher L, Slamon DJ, Murphy M, Novotny WF, Burchmore M, Shak S, Stewart SJ, Press M. Efficacy and safety of trastuzumab as a single agent in firstline treatment of HER2-overexpressing metastatic breast cancer. J Clin Oncol. 2002; 20:719-726.

9. Cobleigh MA, Vogel CL, Tripathy D, Robert NJ, Scholl S, Fehrenbacher L, Wolter JM, Paton V, Shak S, Lieberman G, Slamon DJ. Multinational study of the efficacy and safety of humanized anti-HER 2 monoclonal antibody in women who have HER2-overexpressing metastatic breast cancer that has progressed after chemotherapy for metastatic disease. J Clin Oncol. 1999; 17:2639-2648.

10. Slamon DJ, Leyland-Jones B, Shak S, Fuchs H, Paton V, Bajamonde A, Fleming T, Eiermann W, Wolter J, Pegram M, Baselga J, Norton L. Use of chemotherapy plus a monoclonal antibody against HER2 for metastatic breast cancer that overexpresses HER2. N Engl J Med. 2001; 344:783-792.

11. Seidman AD, Berry D, Cirrincione C, Harris L, Muss H, Marcom PK, Gipson G, Burstein H, Lake D, Shapiro CL, Ungaro P, Norton L, Winer E, et al. Randomized Phase III Trial of Weekly Compared With Every-3-Weeks Paclitaxel for Metastatic Breast Cancer, With Trastuzumab for all HER-2 Overexpressors and Random Assignment to Trastuzumab or Not in HER-2 Nonoverexpressors: Final Results of Cancer and Leukemia Group B Protocol 9840. J Clin Oncol. 2008; 26:1642-1649.

12. Xuan Q, Ji H, Tao X, Xu Y, Zhang Q. Quantitative assessment of HER2 amplification in HER2-positive breast cancer: its association with clinical outcomes. Breast Cancer Res Treat. 2015; 150:581-588.

13. Fuchs E, Köstler WJ, Horvat R, Hudelist G, Kubista E, Attems J, Zielinski CC, Singer CF. High-levelERBB2 gene amplification is associated with a particularly short time-tometastasis, but results in a high rate of complete response once trastuzumab-based therapy is offered in the metastatic setting. Int J Cancer. 2014; 135:224-231.

14. Borley A, Mercer T, Morgan M, Dutton P, Barrett-Lee P, Brunelli M, Jasani B. Impact of HER2 copy number in IHC2+/FISH-amplified breast cancer on outcome of adjuvant trastuzumab treatment in a large UK cancer network. Brit J Cancer. 2014; 110:2139-2143.

15. Vassilakopoulou $M$, Togun $T$, Dafni U, Cheng $H$, Bordeaux J, Neumeister VM, Bobos M, Pentheroudakis G, Skarlos DV, Pectasides D, Kotoula V, Fountzilas G, Rimm DL, et al. In situ quantitative measurement of HER2mRNA predicts benefit from trastuzumab-containing chemotherapy in a cohort of metastatic breast cancer patients. Plos One. 2014; 9:e99131.

16. Perez EA, Hurvitz SA, Amler LC, Mundt KE, Ng V, Guardino E, Gianni L. Relationship between HER2 expression and efficacy with first-line trastuzumab emtansine compared with trastuzumab plus docetaxel in TDM4450g: a randomized phase II study of patients with previously untreated HER2-positive metastatic breast cancer. Breast Cancer Res. 2014; 16:R50.

17. Schneeweiss A, Chia S, Hegg R, Tausch C, Deb R, Ratnayake J, McNally V, Ross G, Kiermaier A, Cortes J. Evaluating the predictive value of biomarkers for efficacy outcomes in response to pertuzumab- and trastuzumabbased therapy: an exploratory analysis of the TRYPHAENA study. Breast Cancer Res. 2014; 16:R73.

18. Kim JW, Kim JH, Im SA, Kim YJ, Han HS, Kim JS, Lee KH, Kim TY, Han SW, Jeon YK, Oh DY, Kim TY, Park IA. HER2/CEP17 ratio and HER2 immunohistochemistry predict clinical outcome after first-line trastuzumab plus taxane chemotherapy in patients with HER2 fluorescence in situ hybridization-positive metastatic breast cancer. Cancer Chemother Pharmacol. 2013; 72:109-115.

19. Bates M, Sperinde J, Kostler WJ, Ali SM, Leitzel K, Fuchs EM, Paquet A, Lie Y, Sherwood T, Horvat R, Singer CF, Winslow J, Weidler JM, et al. Identification of a subpopulation of metastatic breast cancer patients with very high HER2 expression levels and possible resistance to trastuzumab. Ann Oncol. 2011; 22:2014-2020.

20. Joensuu H, Sperinde J, Leinonen M, Huang W, Weidler J, Bono P, Kataja V, Kokko R, Turpeenniemi-Hujanen T, Jyrkkio S, Isola J, Kellokumpu-Lehtinen PL, Paquet A, et al. Very high quantitative tumor HER2 content and outcome in early breast cancer. Ann Oncol. 2011; 22:2007-2013.

21. Toi M, Sperinde J, Huang W, Saji S, Winslow J, Jin X, Tan Y, Ohno S, Nakamura S, Iwata H, Masuda N, Aogi K, Morita S, et al. Differential survival following trastuzumab treatment based on quantitative HER2 expression and HER2 homodimers in a clinic-based cohort of patients with metastatic breast cancer. Bmc Cancer. 2010; 10:56.

22. Perez EA, Reinholz MM, Hillman DW, Tenner KS, Schroeder MJ, Davidson NE, Martino S, Sledge GW, Harris LN, Gralow JR, Dueck AC, Ketterling RP, Ingle JN, et al. HER2 and Chromosome 17 Effect on Patient Outcome in the N9831 Adjuvant Trastuzumab Trial. J Clin Oncol. 2010; 28:4307-4315.

23. Guiu S, Gauthier M, Coudert B, Bonnetain F, Favier L, Ladoire S, Tixier H, Guiu B, Penault-Llorca F, Ettore F, 
Fumoleau P, Arnould L. Pathological complete response and survival according to the level of HER-2 amplification after trastuzumab-based neoadjuvant therapy for breast cancer. Br J Cancer. 2010; 103:1335-1342.

24. Sperinde J, Jin X, Banerjee J, Penuel E, Saha A, Diedrich G, Huang W, Leitzel K, Weidler J, Ali SM, Fuchs EM, Singer CF, Kostler WJ, et al. Quantitation of p95HER2 in Paraffin Sections by Using a p95-Specific Antibody and Correlation with Outcome in a Cohort of TrastuzumabTreated Breast Cancer Patients. Clin Cancer Res. 2010; 16:4226-4235.

25. Lipton A, Köstler WJ, Leitzel K, Ali SM, Sperinde J, Weidler J, Paquet A, Sherwood T, Huang W, Bates M. Quantitative HER2 protein levels predict outcome in fluorescence in situ hybridization-positive patients with metastatic breast cancer treated with trastuzumab. CancerAm Cancer Soc. 2010; 116:5168-5178.

26. Dowsett M, Procter M, McCaskill-Stevens W, de Azambuja E, Dafni U, Rueschoff J, Jordan B, Dolci S, Abramovitz M, Stoss O, Viale G, Gelber RD, PiccartGebhart M, et al. Disease-Free Survival According to Degree of HER2 Amplification for Patients Treated With Adjuvant Chemotherapy With or Without 1 Year of Trastuzumab: The HERA Trial. J Clin Oncol. 2009; 27:2962-2969.

27. Gullo G, Bettio D, Torri V, Masci G, Salvini P, Santoro A. Level of HER2/neu gene amplification as a predictive factor of response to trastuzumab-based therapy in patients with HER2-positive metastatic breast cancer. Invest New Drug. 2009; 27:179-183.

28. Desmedt C, Sperinde J, Piette F, Huang W, Jin X, Tan Y, Durbecq V, Larsimont D, Giuliani R, Chappey C, Buyse M, Winslow J, Piccart M, et al. Quantitation of HER2 expression or HER2:HER2 dimers and differential survival in a cohort of metastatic breast cancer patients carefully selected for trastuzumab treatment primarily by Fish. Diagn Mol Pathol. 2009; 18:22-29.

29. Han H, Kim J, Park JH, Jeon YK, Lee K, Oh D, Kim JH, Park SY, Im S, Kim T, Park IA, Bang Y. Weekly Paclitaxel and Trastuzumab as a First-Line Therapy in Patients with HER2-Overexpressing Metastatic Breast Cancer: Magnitude of HER2/neu Amplification as a Predictive Factor for Efficacy. J Korean Med Sci. 2009; 24:910.

30. Scaltriti M, Rojo F, Ocana A, Anido J, Guzman M, Cortes J, Di Cosimo S, Matias-Guiu X, Ramon Y Cajal S, Arribas J, Baselga J. Expression of p95HER2, a Truncated Form of the HER2 Receptor, and Response to Anti-HER2 Therapies in Breast Cancer. JNCI Journal of the National Cancer Institute. 2007; 99:628-638.

31. Arnould L, Arveux P, Couturier J, Gelly-Marty M, Loustalot C, Ettore F, Sagan C, Antoine M, PenaultLlorca F, Vasseur B, Fumoleau P, Coudert BP. Pathologic Complete Response to Trastuzumab-Based Neoadjuvant Therapy Is Related to the Level of HER-2 Amplification. Clin Cancer Res. 2007; 13:6404-6409.
32. Giuliani R, Durbecq V, Di Leo A, Paesmans M, Larsimont D, Leroy J, Borms M, Vindevoghel A, Jerusalem G, D Hondt V, Dirix L, Canon J, Richard V, et al. Phosphorylated HER-2 tyrosine kinase and Her-2/ neu gene amplification as predictive factors of response to trastuzumab in patients with HER-2 overexpressing metastatic breast cancer (MBC). Eur J Cancer. 2007; 43:725-735.

33. Harris LN, You F, Schnitt SJ, Witkiewicz A, Lu X, Sgroi D, Ryan PD, Come SE, Burstein HJ, Lesnikoski BA, Kamma M, Friedman PN, Gelman R, et al. Predictors of Resistance to Preoperative Trastuzumab and Vinorelbine for HER2-Positive Early Breast Cancer. Clin Cancer Res. 2007; 13:1198-1207.

34. Kong SY, Lee DH, Lee ES, Park S, Lee KS, Ro J. Serum HER2 as a response indicator to various chemotherapeutic agents in tissue HER2 positive metastatic breast cancer. Cancer Res Treat. 2006; 38:35-39.

35. Esteva FJ, Cheli CD, Fritsche H, Fornier M, Slamon D, Thiel RP, Luftner D, Ghani F. Clinical utility of serum HER2/neu in monitoring and prediction of progression-free survival in metastatic breast cancer patients treated with trastuzumab-based therapies. Breast Cancer Res. 2005; 7:R436-R443.

36. Kostler WJ, Schwab B, Singer CF, Neumann R, Rucklinger E, Brodowicz T, Tomek S, Niedermayr M, Hejna M, Steger GG, Krainer M, Wiltschke C, Zielinski CC. Monitoring of serum Her-2/neu predicts response and progression-free survival to trastuzumab-based treatment in patients with metastatic breast cancer. Clin Cancer Res. 2004; 10:1618-1624.

37. Ali SM, Esteva FJ, Fornier M, Gligorov J, Harris L, Koster WJ, Luftner D, Pichon MF, Tse CA, Lipton A. Serum HER-2/neu change predicts clinical outcome to trastuzumab-based therapy. Journal of Clinical Oncology. 2006 ASCO Annual Meeting Proceedings (Post-Meeting Edition). Vol 24, No 18S. 2006; 500.

38. Paik S, Kim C, Jeong J, Geyer CE, Romond EH, MejiaMejia O, Mamounas EP, Wickerham D, Costantino JP, Wolmark N. Benefit from adjuvant trastuzumab may not be confined to patients with IHC 3+ and/or FISH-positive tumors: Central testing results from NSABP B-31. Journal of Clinical Oncology. 2007 ASCO Annual Meeting Proceedings (Post-Meeting Edition). 2007; 25:511.

39. Kaufman PA, Broadwater G, Lezon-Geyda K, Dressler LG, Berry D, Friedman P, Winer EP, Hudis C, Ellis MJ, Seidman AD, Harris LN. CALGB 150002: Correlation of HER2 and chromosome 17 (ch17) copy number with trastuzumab (T) efficacy in CALGB 9840, paclitaxel (P) with or without $\mathrm{T}$ in HER2+ and HER2- metastatic breast cancer (MBC). Journal of Clinical Oncology. 2007 ASCO Annual Meeting Proceedings (Post-Meeting Edition). 2007; 25:1009.

40. Arnould L, Arveux P, Couturier J, Gelly-Marty M, Loustalot C, Ettore F, Sagan C, Antoine M, Penault- 
Llorca F, Vasseur B, Fumoleau P, Coudert BP. Pathologic Complete Response to Trastuzumab-Based Neoadjuvant Therapy Is Related to the Level of HER-2 Amplification. Clin Cancer Res. 2007; 13:6404-6409.

41. Schneeweiss A, Chia S, Hegg R, Tausch C, Deb R, Ratnayake J, McNally V, Ross G, Kiermaier A, Cortes J. Evaluating the predictive value of biomarkers for efficacy outcomes in response to pertuzumab- and trastuzumabbased therapy: an exploratory analysis of the TRYPHAENA study. Breast Cancer Res. 2014; 16:R73.

42. Guiu S, Gauthier M, Coudert B, Bonnetain F, Favier L, Ladoire S, Tixier H, Guiu B, Penault-Llorca F, Ettore F, Fumoleau P, Arnould L. Pathological complete response and survival according to the level of HER-2 amplification after trastuzumab-based neoadjuvant therapy for breast cancer. Br J Cancer. 2010; 103:1335-1342.

43. Vassilakopoulou $M$, Togun $T$, Dafni $U$, Cheng $H$, Bordeaux J, Neumeister VM, Bobos M, Pentheroudakis G, Skarlos DV, Pectasides D, Kotoula V, Fountzilas G, Rimm DL, et al. In situ quantitative measurement of HER2mRNA predicts benefit from trastuzumab-containing chemotherapy in a cohort of metastatic breast cancer patients. Plos One. 2014; 9:e99131.

44. Han H, Kim J, Park JH, Jeon YK, Lee K, Oh D, Kim JH, Park SY, Im S, Kim T, Park IA, Bang Y. Weekly Paclitaxel and Trastuzumab as a First-Line Therapy in Patients with HER2-Overexpressing Metastatic Breast Cancer: Magnitude of HER2/neu Amplification as a Predictive Factor for Efficacy. J Korean Med Sci. 2009; 24:910.

45. Fuchs E, Köstler WJ, Horvat R, Hudelist G, Kubista E, Attems J, Zielinski CC, Singer CF. High-levelERBB2 gene amplification is associated with a particularly short time-tometastasis, but results in a high rate of complete response once trastuzumab-based therapy is offered in the metastatic setting. Int J Cancer. 2014; 135:224-231.

46. Giuliani R, Durbecq V, Di Leo A, Paesmans M, Larsimont D, Leroy J, Borms M, Vindevoghel A, Jerusalem G, D Hondt V, Dirix L, Canon J, Richard V, et al. Phosphorylated HER-2 tyrosine kinase and Her-2/ neu gene amplification as predictive factors of response to trastuzumab in patients with HER-2 overexpressing metastatic breast cancer (MBC). Eur J Cancer. 2007; 43:725-735.

47. Kim JW, Kim JH, Im SA, Kim YJ, Han HS, Kim JS, Lee KH, Kim TY, Han SW, Jeon YK, Oh DY, Kim TY, Park IA. HER2/CEP17 ratio and HER2 immunohistochemistry predict clinical outcome after first-line trastuzumab plus taxane chemotherapy in patients with HER2 fluorescence in situ hybridization-positive metastatic breast cancer. Cancer Chemother Pharmacol. 2013; 72:109-115.

48. Perez EA, Hurvitz SA, Amler LC, Mundt KE, Ng V, Guardino E, Gianni L. Relationship between HER2 expression and efficacy with first-line trastuzumab emtansine compared with trastuzumab plus docetaxel in TDM4450g: a randomized phase II study of patients with previously untreated HER2-positive metastatic breast cancer. Breast Cancer Res. 2014; 16:R50.

49. 2016/5/22 CALGB 150002: Correlation of HER2 and chromosome 17 (ch17) copy number with trastuzumab (T) efficacy in CALGB 9840, paclitaxel (P) with or wi.

50. Gullo G, Bettio D, Torri V, Masci G, Salvini P, Santoro A. Level of HER2/neu gene amplification as a predictive factor of response to trastuzumab-based therapy in patients with HER2-positive metastatic breast cancer. Invest New Drug. 2009; 27:179-183.

51. 2016/5/22 Serum HER-2/neu change predicts clinical outcome to trastuzumab-based therapy-Ali et al. 24 (18 Supplement): 500-ASCO Meeting Abstracts..

52. Esteva FJ, Cheli CD, Fritsche H, Fornier M, Slamon D, Thiel RP, Luftner D, Ghani F. Clinical utility of serum HER2/neu in monitoring and prediction of progression-free survival in metastatic breast cancer patients treated with trastuzumab-based therapies. Breast Cancer Res. 2005; 7:R436-R443.

53. Kong SY, Lee DH, Lee ES, Park S, Lee KS, Ro J. Serum HER2 as a response indicator to various chemotherapeutic agents in tissue HER2 positive metastatic breast cancer. Cancer Res Treat. 2006; 38:35-39.

54. Kostler WJ, Schwab B, Singer CF, Neumann R, Rucklinger E, Brodowicz T, Tomek S, Niedermayr M, Hejna M, Steger GG, Krainer M, Wiltschke C, Zielinski CC. Monitoring of serum Her-2/neu predicts response and progression-free survival to trastuzumab-based treatment in patients with metastatic breast cancer. Clin Cancer Res. 2004; 10:1618-1624.

55. Bates M, Sperinde J, Kostler WJ, Ali SM, Leitzel K, Fuchs EM, Paquet A, Lie Y, Sherwood T, Horvat R, Singer CF, Winslow J, Weidler JM, et al. Identification of a subpopulation of metastatic breast cancer patients with very high HER2 expression levels and possible resistance to trastuzumab. Ann Oncol. 2011; 22:2014-2020.

56. Toi M, Sperinde J, Huang W, Saji S, Winslow J, Jin X, Tan Y, Ohno S, Nakamura S, Iwata H, Masuda N, Aogi K, Morita S, et al. Differential survival following trastuzumab treatment based on quantitative HER2 expression and HER2 homodimers in a clinic-based cohort of patients with metastatic breast cancer. Bmc Cancer. 2010; 10:56.

57. Lipton A, Köstler WJ, Leitzel K, Ali SM, Sperinde J, Weidler J, Paquet A, Sherwood T, Huang W, Bates M. Quantitative HER2 protein levels predict outcome in fluorescence in situ hybridization-positive patients with metastatic breast cancer treated with trastuzumab. CancerAm Cancer Soc. 2010; 116:5168-5178.

58. Desmedt C, Sperinde J, Piette F, Huang W, Jin X, Tan Y, Durbecq V, Larsimont D, Giuliani R, Chappey C, Buyse M, Winslow J, Piccart M, et al. Quantitation of HER2 expression or HER2:HER2 dimers and differential survival in a cohort of metastatic breast cancer patients carefully selected for trastuzumab treatment primarily by FISH. Diagn Mol Pathol. 2009; 18:22-29. 
59. Sperinde J, Jin X, Banerjee J, Penuel E, Saha A, Diedrich G, Huang W, Leitzel K, Weidler J, Ali SM, Fuchs EM, Singer CF, Kostler WJ, et al. Quantitation of p95HER2 in Paraffin Sections by Using a p95-Specific Antibody and Correlation with Outcome in a Cohort of TrastuzumabTreated Breast Cancer Patients. Clin Cancer Res. 2010; 16:4226-4235.

60. Scaltriti M, Rojo F, Ocana A, Anido J, Guzman M, Cortes J, Di Cosimo S, Matias-Guiu X, Ramon YCS, Arribas J, Baselga J. Expression of p95HER2, a truncated form of the HER2 receptor, and response to anti-HER2 therapies in breast cancer. J Natl Cancer Inst. 2007; 99:628-638.

61. 2016/5/14 Benefit from adjuvant trastuzumab may not be confined to patients with IHC $3+$ and/or FISH-positive tumors: Central testing results from NSABP B-31.

62. Perez EA, Reinholz MM, Hillman DW, Tenner KS, Schroeder MJ, Davidson NE, Martino S, Sledge GW, Harris LN, Gralow JR, Dueck AC, Ketterling RP, Ingle JN, et al. HER2 and Chromosome 17 Effect on Patient Outcome in the N9831 Adjuvant Trastuzumab Trial. J Clin Oncol. 2010; 28:4307-4315.

63. Dowsett M, Procter M, McCaskill-Stevens W, de Azambuja E, Dafni U, Rueschoff J, Jordan B, Dolci S, Abramovitz M, Stoss O, Viale G, Gelber RD, PiccartGebhart M, et al. Disease-Free Survival According to Degree of HER2 Amplification for Patients Treated With Adjuvant Chemotherapy With or Without 1 Year of Trastuzumab: The HERA Trial. J Clin Oncol. 2009; 27:2962-2969.

64. Borley A, Mercer T, Morgan M, Dutton P, Barrett-Lee P, Brunelli M, Jasani B. Impact of HER2 copy number in IHC2+/FISH-amplified breast cancer on outcome of adjuvant trastuzumab treatment in a large UK cancer network. Brit J Cancer. 2014; 110:2139-2143.

65. Xuan Q, Ji H, Tao X, Xu Y, Zhang Q. Quantitative assessment of HER2 amplification in HER2-positive breast cancer: its association with clinical outcomes. Breast Cancer Res Treat. 2015; 150:581-588.

66. Xuan Q, Ji H, Tao X, Xu Y, Zhang Q. Quantitative assessment of HER2 amplification in HER2-positive breast cancer: its association with clinical outcomes. Breast Cancer Res Tr. 2015; 150:581-588.

67. Borley A, Mercer T, Morgan M, Dutton P, Barrett-Lee P, Brunelli M, Jasani B. Impact of HER2 copy number in IHC2+/FISH-amplified breast cancer on outcome of adjuvant trastuzumab treatment in a large UK cancer network. Brit J Cancer. 2014; 110:2139-2143.

68. Dowsett M, Procter M, McCaskill-Stevens W, de Azambuja E, Dafni U, Rueschoff J, Jordan B, Dolci S, Abramovitz M, Stoss O, Viale G, Gelber RD, PiccartGebhart M, et al. Disease-free survival according to degree of HER2 amplification for patients treated with adjuvant chemotherapy with or without 1 year of trastuzumab: the HERA Trial. J Clin Oncol. 2009; 27:2962-2969.

69. Schneeweiss A, Chia S, Hegg R, Tausch C, Deb R, Ratnayake J, McNally V, Ross G, Kiermaier A, Cortenulls J. Evaluating the predictive value of biomarkers for efficacy outcomes in response to pertuzumab- and trastuzumabbased therapy: An exploratory analysis of the TRYPHAENA study. Breast Cancer Res. 2014; 16.

70. Arnould L, Arveux P, Couturier J, Gelly-Marty M, Loustalot C, Ettore F, Sagan C, Antoine M, PenaultLlorca F, Vasseur B, Fumoleau P, Coudert BP. Pathologic complete response to trastuzumab-based neoadjuvant therapy is related to the level of HER-2 amplification. Clin Cancer Res. 2007; 13:6404-6409.

71. Guiu S, Gauthier M, Coudert B, Bonnetain F, Favier L, Ladoire S, Tixier H, Guiu B, Penault-Llorca F, Ettore F, Fumoleau P, Arnould L. Pathological complete response and survival according to the level of HER-2 amplification after trastuzumab-based neoadjuvant therapy for breast cancer. Br J Cancer. 2010; 103:1335-1342.

72. Giuliani R, Durbecq V, Di Leo A, Paesmans M, Larsimont D, Leroy JY, Borms M, Vindevoghel A, Jerusalem G, D'Hondt V, Dirix L, Canon JL, Richard V, et al. Phosphorylated HER-2 tyrosine kinase and Her-2/ neu gene amplification as predictive factors of response to trastuzumab in patients with HER-2 overexpressing metastatic breast cancer (MBC). Eur J Cancer. 2007; 43:725-735.

73. Liberati A, Altman DG, Tetzlaff J, Mulrow C, Gotzsche PC, Ioannidis JP, Clarke M, Devereaux PJ, Kleijnen J, Moher D. The PRISMA statement for reporting systematic reviews and meta-analyses of studies that evaluate health care interventions: explanation and elaboration. J Clin Epidemiol. 2009; 62:e1-e34.

74. Tierney JF, Stewart LA, Ghersi D, Burdett S, Sydes MR. Practical methods for incorporating summary time-to-event data into meta-analysis. Trials. 2007; 8:16.

75. Sterne JAC, Sutton AJ, Ioannidis JPA, Terrin N, Jones DR, Lau J, Carpenter J, Rucker G, Harbord RM, Schmid CH, Tetzlaff J, Deeks JJ, Peters J, et al. Recommendations for examining and interpreting funnel plot asymmetry in meta-analyses of randomised controlled trials. BMJ. 2011; 343:d4002. 